\title{
Integration of gene expression and DNA methylation profiles provides a molecular subtype for risk assessment in atherosclerosis
}

\author{
SHENG-CHAO MA ${ }^{1,2^{*}}$, HUI-PING ZHANG ${ }^{3 *}$, FAN-QI KONG ${ }^{2}$, HUI ZHANG $^{2}$, \\ CHENG YANG $^{2}$, YANG-YANG HE ${ }^{2}$, YAN-HUA WANG ${ }^{2}$, AN-NING YANG ${ }^{2}$, JU TIAN ${ }^{2}$, \\ XIAO-LING YANG ${ }^{2}$, MING-HAO ZHANG ${ }^{2}$, HUA XU $^{2}$, YI-DENG JIANG ${ }^{2}$ and ZHENG YU ${ }^{1}$
}

\begin{abstract}
${ }^{1}$ Department of Physiology, West China School of Preclinical and Forensic Medicine, Sichuan University, Chengdu, Sichuan 610041; ${ }^{2}$ Department of Pathophysiology, Basic Medical School, Ningxia Medical University; ${ }^{3}$ Department of Prenatal Diagnosis Center, General Hospital of Ningxia Medical University, Yinchuan, Ningxia Hui 750004, P.R. China
\end{abstract}

Received April 27, 2015; Accepted February 29, 2016

DOI: $10.3892 / \mathrm{mmr} .2016 .5120$

\begin{abstract}
The aim of the present study was to identify an effective method for detecting early-phase atherosclerosis (AS), as well as to provide useful DNA methylation profiles to serve as biomarkers for the detection of AS. A total of 300 individuals (150 AS patients and 150 healthy subjects) were recruited for peripheral blood DNA methylation analyses at 12 gene promoter loci using nested methylation-specific polymerase chain reaction in a test set. Based on the test set, the promoter methylation of TIMP metallopeptidase inhibitor 1 (TIMP1), ATP binding cassette subfamily A member 1 ( $A B C A 1)$, and acetyl-CoA acetyltransferase 1 (ACAT1) were determined to be candidate biomarkers; demonstrating the highest sensitivity (88\%) and specificity (90\%). The biomarkers that were candidates for early AS detection were validated in an independent validation set $(\mathrm{n}=100)$. In the validation set, the combination of TIMP1, ABCA1 and ACAT1 methylation achieved sensitivity, specificity and coincidence rate values of 88,70 and $79 \%$, respectively. In the current pilot study, the patterns of DNA methylation of AS-associated genes were observed to be significantly altered in the peripheral blood of AS patients. Thus, the AS-specific methylation of the three-gene
\end{abstract}

Correspondence to: Professor Yi-Deng Jiang, Department of Pathophysiology, Basic Medical School, Ningxia Medical University, Shengli Street, Yinchuan, Ningxia Hui 750004, P.R. China

E-mail: jydcan@126.com

Professor Zheng Yu, Department of Physiology, West China School of Preclinical and Forensic Medicine, Sichuan University, Chengdu, Sichuan 610041, P.R. China

E-mail: yuzhchuanda@163.com

*Contributed equally

Key words: DNA methylation profiles, $\mathrm{CpG}$ islands, atherosclerosis panel (TIMP1, ABCA1, and ACAT1) may serve as a valuable biomarker for the early detection of AS.

\section{Introduction}

Atherosclerosis (AS) of the carotid arteries is a major cause of stroke and transient ischemic attack, which remains the leading cause of mortality in China and is currently the most common cause of mortality worldwide $(1,2)$. The symptoms of AS are not always detected by patients until complications arise and the therapeutic methods to treat AS are poor; therefore, it is particularly important to establish an appropriate, rigorous and efficient detection strategy for early-phase AS, in order to limit disease progression before it results in clinical consequences (3). There are two prevalent methods for diagnosing AS: Doppler ultrasound and computed tomographic angiography (CTA), which have become the standard methods for diagnosing AS $(4,5)$. However, neither of these methods identify the early asymptomatic pathological changes of AS and ultrasound only assesses plaque in the carotid artery. Therefore, it is paramount to develop non-invasive methods for diagnosing high-risk, asymptomatic individuals before the onset of clinical events or symptoms $(6,7)$. Furthermore, data supporting the routine use of Doppler ultrasound to screen for carotid stenosis in an asymptomatic population is considered to be weak, as there is a low overall prevalence of treatable AS in the general asymptomatic population (8). It is widely hypothesized that the next generation of screening tests will be based on molecular biomarkers (9).

DNA methylation, a stable epigenetic mark, is a non-traditional, heritable factor involved in gene transcription regulation (10). DNA methylation occurs at position $5^{\prime}$ of $\mathrm{CpG}$ dinucleotides; certain regions of DNA are rich in $\mathrm{CpG}$ and are termed $\mathrm{CpG}$ islands (GCIs), which predominantly locate in the promoter region (11). Changes in patterns of DNA methylation may lead to inappropriate gene expression, and contribute to the development and progression of disease (12). In addition, previous studies have demonstrated aberrant DNA methylation in AS (13). Alterations in DNA 
methylation have been identified as an early event in AS; Zhao et al (14) found that aberrant methylation may represent an early biomarker for AS, and demonstrated clinical correlations with carotid intima-media thickness (14). Current research primarily focuses on the effect of DNA methylation leading to AS and, to the best of our knowledge, there are few studies that investigate the role of DNA methylation on the early diagnosis of AS. Detection of DNA methylation, at candidate loci in AS, suggests that AS-specific methylation changes could be applied diagnostically. However, DNA methylation affects various factors, including age, living environment, diet and other factors limit the use of methylation changes for diagnosis. Previous studies have shown that simultaneous measure various differentially methylated loci may improve diagnostic use (15). Furthermore, a major limitation towards further developments of DNA methylation in clinical use may be that the majority of studies focus on single genes (16), whereas AS is associated with multiple factors, including genetic and epigenetic alterations (17). Measuring the methylation of individual genes was not as specific or sensitive as using a panel of epigenetic markers for the early detection of breast cancer (18).

In the present study, DNA methylation was profiled in AS and healthy groups of 300 patients using nested methylation-specific polymerase chain reaction (PCR; NT-MSP). Based in previous unpublished data, a biomarker panel capable of differentiating AS patients from healthy individuals, irrespective of AS histology, was identified. The present study provides insight into AS etiology, presents validated tissue-based diagnostic biomarkers, and supplies a framework for the development of DNA methylation-based molecular diagnostics for AS detection in patients.

\section{Materials and methods}

Ethics statement. The present study was reviewed and approved by the Ethics Committee of General Hospital of Ningxia Medical University (Yinchuan, China). Written informed consent was obtained from the participants before the collection of any samples and the specimens were irreversibly de-identified.

Inclusion and exclusion criteria. Patients with AS were diagnosed by Doppler ultrasound examination of the carotid artery. The healthy control group comprised of age- and gender-matched healthy individuals that were not exhibiting AS risk factors. The exclusion criteria were as follows: Individuals with moderate or severe valvular heart disease, chronic renal failure or diabetes; smokers; obese individuals; and those exhibiting disordered lipid metabolism.

NT-MSP analysis of DNA methylation. The following candidate genes formed the panel for early detection of AS: ATP binding cassette subfamily A member 1 ( $A B C A 1)$, acetylCoA acetyltransferase 1 (ACAT1), peroxisome proliferator activated receptor $\alpha(P P A R A)$, platelet derived growth factor subunit $\mathrm{B}(P D G F B)$, arachidonate 5-lipoxygenase (ALOX5), LDL receptor related protein 1 ( $L R P I)$, lecithin-cholesterol acyltransferase (LCAT), TIMP metallopeptidase inhibitor 1 (TIMP1), matrix metallopeptidase 9 (MMP9), intercellular adhesion molecule 1 (ICAMI), vascular endothelial growth factor $\mathrm{A}(V E G F A)$ and nuclear factor of $\kappa$ light polypeptide gene enhancer in B-cells 1 ( NFKBl). These genes contained CGIs, were expressed in peripheral blood cells, and were correlated with the occurrence and development of AS (19-24). DNA methylation of these candidate genes was examined in two independent test sets (total of 300 peripheral blood samples) and genomic DNA was isolated from the peripheral blood mononuclear cells using the Wizard Genomic DNA Purification kit (Promega Corporation, Madison, WI, USA). An EZ DNA Methylation-Gold ${ }^{\mathrm{TM}}$ kit (Zymo Research Corporation, Irvine, CA, USA) was used to detect the DNA methylation patterns, and integrates the DNA denaturation and bisulfite conversion processes into one step. The DNA was modified by sodium bisulfite (Zymo Research Corporation, Irvine, CA, USA) in which unmethylated cytosine residues were converted to thymine, whereas methylated cytosine residues were retained as cytosine; this difference was then utilized to specifically amplify either methylated or unmethylated DNA. NT-MSP, which consists of a two-step PCR amplification, was then used to detect methylation (25). The first step of NT-MSP uses an outer primer pair, which does not contain any $\mathrm{CpGs}$. The second step of PCR was conducted with conventional PCR primers serving as inner primers. The primers for NT-MSP amplification were designed according to the bioinformatics program, MethPrimer (www.urogene.org/methprimer/index.html) and are presented in Table I. PCR products were gel purified with an agarose gel DNA fragment recovery kit, according to the manufacturer's instructions, and were sequenced by Invitrogen (Thermo Fisher Scientific, Inc., Waltham, MA, USA). To reduce mispriming and to increase efficiency, touchdown (TD) PCR was used for amplification. Samples were subjected to 30 cycles in a TD program $\left(94^{\circ} \mathrm{C}\right.$ for $5 \mathrm{~min}, 94^{\circ} \mathrm{C}$ for $30 \mathrm{sec} ; 56^{\circ} \mathrm{C}$ for $30 \mathrm{sec}$ and $72^{\circ} \mathrm{C}$ for $1 \mathrm{~min}$, followed by a decrease of $0.5^{\circ} \mathrm{C}$ in the annealing temperature every second cycle). After completion of the TD program, 20 cycles were subsequently run $\left(94^{\circ} \mathrm{C}\right.$ for $30 \mathrm{sec}, 56^{\circ} \mathrm{C}$ for $30 \mathrm{sec}$ and $72^{\circ} \mathrm{C}$ for $60 \mathrm{sec}$ ), terminating with a 7 -min extension at $72^{\circ} \mathrm{C}$. The PCR products were separated by electrophoresis through a $2 \%$ agarose gel (Borunlaite Science \& Technology, Beijing, China) containing ethidium bromide (Tokyo Chemical Industry Co., Ltd., Shanghai, China) for $30 \mathrm{~min}$ at $100 \mathrm{~V}$. The DNA bands were visualized using ultraviolet light. The following formula was used: Methylation \%= methylation / (methylation + unmethylation) $\mathrm{x} 100 \%$.

Reverse transcription-quantitative PCR (RT-qPCR) for $m R N A$. The total RNA was extracted from the peripheral blood mononuclear cells using Invitrogen TRIzol reagent (Thermo Fisher Scientific, Inc.). Primer Premier 5 software was used to design the primers (Table II). The expression levels of candidate genes were normalized to those of glyceraldehyde-3-phosphate dehydrogenase (GAPDH): Forward, 5'-AGAAGGCTGGGGCTCATTTG-3', and reverse, 5'-AGGGGCCATCCACAGTCTTC-3'. RNA was reverse transcribed using the PrimeScript Real-Time PCR reagent kit (Invitrogen; Thermo Fisher Scientific, Inc.) according to the manufacturer's instructions. Total RNA then underwent 
Table I. Primer sequences for DNA methylation analysis.

Primer sequence (5'-3')

\begin{tabular}{|c|c|c|}
\hline Gene & Forward & Reverse \\
\hline \multicolumn{3}{|l|}{$A B C A 1$} \\
\hline Outer & GAAAGTAGGATTTAGAGGAAGTAAAT & ААТТСААТСАСТСААСААААААCAC \\
\hline Methylation & AATTTTATTGGTGTTTTTGGTTGTC & ATATCTTAAAATCCGCGATCTACG \\
\hline Unmethylation & AATTTTATTGGTGTTTTTGGTTGTT & САAАТАТСТТААААТССАСААТСТА \\
\hline \multicolumn{3}{|l|}{ ACATl } \\
\hline Outer & AGGAAGATTTAGAGATTTAGAAGTAA & TCAATAATCACTCAAACACACAA \\
\hline Methylation & TTAATTAGTTTGGTTTTTGGTCGTT & CTTATATACCAAATGCGAACT \\
\hline Unmethylation & TTAATTATGTGTGTTTGGTTTTTTG & TATCCAAATTAACCAAACTCCATA \\
\hline \multicolumn{3}{|l|}{$P D G F B$} \\
\hline Outer & TTTTTTTGTTTTGAAATTTTGGTTAA & CAAAATCCCAACAAAAATCTCC \\
\hline Methylation & TTTGGAAATTAATGATAAGTTAGGC & AAGCATCATAAAAAAAACGCATC \\
\hline Unmethylation & TTGGAAATTAATGATAAGTTAGGTGA & AAACATCATAAAAAAAACACATCA \\
\hline \multicolumn{3}{|l|}{ ALOX5 } \\
\hline Outer & TTATATTTTCGTCGTTTTACGTACG & AATATAAAAAAAATTTCGCGCG \\
\hline Methylation & TATATTTTTGTTGTTTTATGTATGG & AAATATAAAAAAAATTACACACT \\
\hline Unmethylation & AGATGTTATAGGGATTTTGTTGTTT & TCTAAAACACAAAAАСТCТСААС \\
\hline \multicolumn{3}{|l|}{ LRP1 } \\
\hline Outer & TTTGTTGTTTAGGTTGGAGTGTAGT & TAAAAAAATCACTTTTAAAAATTC \\
\hline Methylation & TGTTTAGGTTGGAGTGTAGTGGTAC & AAAAAATCACTTTTCAAAATTCGA \\
\hline Unmethylation & TGTTTAGGTTGGAGTGTAGTGGTAT & AАAАATCACTTTTCAАAАТTCAАA \\
\hline \multicolumn{3}{|l|}{$L C A T$} \\
\hline Outer & GAGTTTTTTGTTTTGTTTTGGTTTC & AАTCTTAATCAATCTATCTACCGC \\
\hline Methylation & GAGTTTTTTGTTTTGTTTTGGTTTT & ATCTTAATCAATCCATCTACCACA \\
\hline Unmethylation & TTTGGTTGTTTTTTTGTATTATTTG & TCAATCTTAATCAACTCATCTACC \\
\hline \multicolumn{3}{|l|}{ TIMP1 } \\
\hline Outer & TTTTTTTTAATGTTTATTTATTTATT & ССАААСАСТСАСААТТТАТСТСАС \\
\hline Methylation & TTAGGTAGTTTTTGTTTGAATTTCG & ATAAATACCGTTCTTATTCCCGTT \\
\hline Unmethylation & TAGGTAGTTTTTGTTTGAATTTTGG & ATAAATACCAATTCTTATTCCСАTТ \\
\hline \multicolumn{3}{|l|}{ MMP9 } \\
\hline Outer & GGTTATATAGTTGGAAATGGTAGAGT & ATTCAАACAАТTCТСТАССТСААС \\
\hline Methylation & TTTTAAATATAGTTTATTGGGTCGG & TTTAATAAAAATAAAATTTCACTA \\
\hline Unmethylation & TTTTTTAAATATAGTTTATTGGGTTGG & AATAAAAATAAATTTCACТАСАТT \\
\hline \multicolumn{3}{|l|}{ ICAMI } \\
\hline Outer & GTAAGAGTTTAGTGGAATTCGTTCG & GAATCACTAACCATCCAAAAACG \\
\hline Methylation & TAAGAGTTTAGTGGAATTTGTTTGA & AAATCACTAACCATCCAAAAACAC \\
\hline Unmethylation & TAAGAGTTTAGTGGAATTTGTTTGA & ССТААААСТТТССТАТТАТААААС \\
\hline \multicolumn{3}{|l|}{$V E G F A$} \\
\hline Outer & TAGTTAGAGTCGGGGTGTGTAGAC & GAAAAACCGAACAAAAACGAA \\
\hline Methylation & TAGTTAGAGTTGGGGTGTGTAGATG & AACAAAAAACCAACAAAAACAAA \\
\hline Unmethylation & GGAGTAAATTTTTTTTATTTTTTTT & ATTGTGGTTTTTGGTTTAGTTTTG \\
\hline \multicolumn{3}{|l|}{ PPARA } \\
\hline Outer & AGTATAGTGGTATAGGGTATTGGTAG & TAAAACTCTACAAAACAAAAAAAA \\
\hline Methylation & TAGTGGTAGGTATAGTTGGTAGCGG & ACCAATAACGAAAATAAAAAAAC \\
\hline Unmethylation & TAGTGGTAGGTATAGTTGGTAGTGG & CAATAACAAAATAAAAAAACACC \\
\hline \multicolumn{3}{|l|}{$N F K B 1$} \\
\hline Outer & TATAGATGAGTTTTATTTATTTGGTA & АААСТСТААСТССТААСААААC \\
\hline Methylation & TTGATTGGGTTCGGTAGGC & GCACTTCTAAAAAGCTATACGCC \\
\hline Unmethylation & TTATTGATTGGGTTTGGTAGGT & СССАСАСТТСТААСАСТАТАСАСС \\
\hline
\end{tabular}


Table II. Primers used in quantitative polymerase chain reaction for mRNA analysis.

\begin{tabular}{|c|c|c|c|}
\hline Gene & Primer & Sequence $\left(5^{\prime}-3^{\prime}\right)$ & Product size (bp) \\
\hline$A C A T 1$ & $\begin{array}{l}\text { Left } \\
\text { Right }\end{array}$ & $\begin{array}{l}\text { ACGCTGCTGTAGAACCTATTGA } \\
\text { GGCTTCATTTACTTCCCACATT }\end{array}$ & 116 \\
\hline$A B C A 1$ & $\begin{array}{l}\text { Left } \\
\text { Right }\end{array}$ & $\begin{array}{l}\text { ATCAAGGGCATCGTGTATGAG } \\
\text { AGGATTGTCACCACAGCAAAC }\end{array}$ & 227 \\
\hline PPARA & $\begin{array}{l}\text { Left } \\
\text { Right }\end{array}$ & $\begin{array}{l}\text { ATCACGGAACACGCTTTCAC } \\
\text { CGATGTTCAATGCTCCACTG }\end{array}$ & 100 \\
\hline$T I M P 1$ & $\begin{array}{l}\text { Left } \\
\text { Right }\end{array}$ & $\begin{array}{l}\text { ATACTTCCACAGGTCCCACAAC } \\
\text { GGATGGATAAACAGGGAAACAC }\end{array}$ & 194 \\
\hline$A L O X 5$ & $\begin{array}{l}\text { Left } \\
\text { Right }\end{array}$ & $\begin{array}{l}\text { AGTTCCAGCAAGGGAACATT } \\
\text { CATCCGAAGGGAGGAAAATAG }\end{array}$ & 204 \\
\hline
\end{tabular}

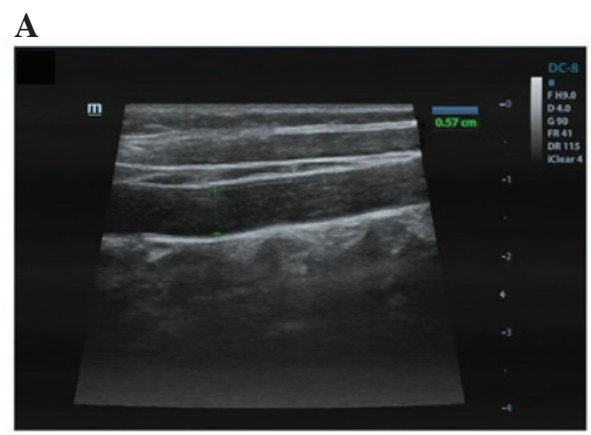

B

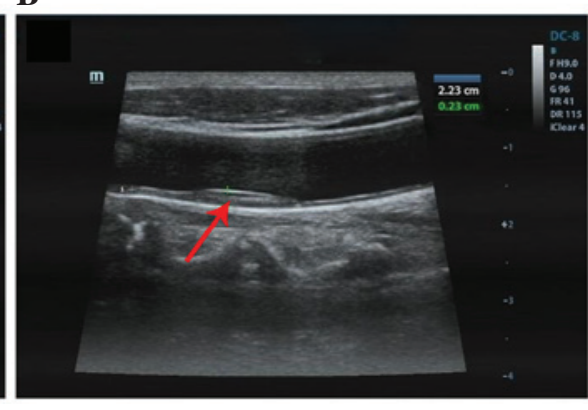

C

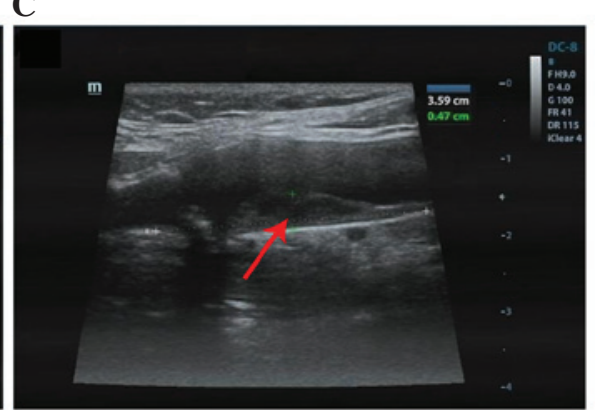

Figure 1. Carotid artery plaques detected by Doppler ultrasound. (A) Carotid artery in the healthy control group. (B) Carotid atherosclerosis plaque sonograms from patients with (B) minor (plague area, $0.23 \times 2.23 \mathrm{~cm}$ ) and $(\mathrm{C})$ severe (plague area, $0.47 \times 3.59 \mathrm{~cm}$ ) lesions. Sonograms were performed on the right side of the carotid artery to atherosclerosis plaques. Plaques are demonstrated by the red arrows.

cDNA synthesis and PCR amplification using the PrimeScript Real-Time PCR reagent kit according to the manufacturer's instructions. The qPCR reaction was performed following the manufacturer's instructions, as follows: Denaturation at $94^{\circ} \mathrm{C}$ for $10 \mathrm{~min}, 50$ cycles at $94^{\circ} \mathrm{C}$ for $15 \mathrm{sec}$, annealing at $53^{\circ} \mathrm{C}$ for $30 \mathrm{sec}$ and extension at $72^{\circ} \mathrm{C}$ for $30 \mathrm{sec}$. The RNA level of every gene was acquired from the value of the quantitation cycle $(\mathrm{Cq})$ of the qPCR normalized to that of GAPDH using the following formula: $\Delta_{\mathrm{Cq}}=\mathrm{Cq}_{\mathrm{GAPDH}}-\mathrm{Cq}_{\text {gene }}$. The final results were expressed as the $\mathrm{N}$-fold differences in the target gene expression and was relative to the calibrator, termed $\mathrm{N}_{\text {target }}$, which was determined as follows: $\mathrm{N}_{\text {target }}=2^{\Delta \mathrm{Cq} \text { (sample)- } \Delta \text { Cq(calibrator) }}$, where $\Delta_{\mathrm{Cq}}$ values of the calibrator and sample were determined by subtracting the $\mathrm{Cq}$ value of the target gene from the $\mathrm{Cq}$ value of GAPDH.

Statistical analysis. The patient characteristics were compared with those of the control subjects using the $\chi^{2}$ test and the independent-samples $t$-test was used to detect significantly different methylation levels between the AS patients and matched controls. Receiver-operating-characteristics (ROC) curves were calculated to evaluate the diagnostic performance of different marker combinations. Furthermore, sensitivity and specificity analyses were performed to assess different marker combinations for AS detection. $\mathrm{P}<0.05$ was considered to indicate a statistically significant difference.

\section{Results}

Doppler ultrasound of carotid artery samples. All participants in the test and validation sets were verified by Doppler ultrasound. Images of carotid arteries of the healthy control subjects are presented in Fig. 1A, the samples demonstrate intima-media with no plaques and normal blood flow. Conversely, Doppler flow imaging of the patients with AS demonstrated anterior wall filling defects in the carotid artery, as shown in Fig. 1B and C. Furthermore, the plaque area was $0.23 \times 2.23 \mathrm{~cm}$ in Fig. $1 \mathrm{~B}$ and $0.47 \times 3.59 \mathrm{~cm}$ in Fig. 1C.

Subject recruitment and collection of blood samples. A total of 300 peripheral blood samples were assessed in this case-control study, which included samples from AS patients and healthy control subjects. Between June 2011 and March 2012150 patients and 150 healthy subjects (who had undergone Doppler ultrasound) were enrolled from the General Hospital of Ningxia Medical University for the test study. All participants were human immunodeficiency virus-, hepatitis B virus-, and hepatitis B virus-negative and did not exhibit inflammation or liver and kidney diseases. Furthermore, they did not have any previous history of cancer and were not pregnant. AS is often accompanied by lipid abnormalities; in the present study, AS patients demonstrated higher levels of 
Table III. Demographic characteristics of study subjects.

\begin{tabular}{|c|c|c|c|}
\hline \multirow[b]{2}{*}{ Characteristic } & \multicolumn{2}{|c|}{ Groups } & \multirow[b]{2}{*}{$\mathrm{P}$-value } \\
\hline & Matched control (\%) & $\mathrm{AS}(\%)$ & \\
\hline Gender ratio (male/female) & $70 / 80$ & $60 / 90$ & 0.1359 \\
\hline \multicolumn{4}{|l|}{ Age (years) } \\
\hline $30-40$ & 63 & 18 & \\
\hline $41-49$ & 55 & 50 & 0.3791 \\
\hline $51-60$ & 32 & 87 & \\
\hline Alcohol & 25 & 45 & 0.2852 \\
\hline Smoking & 48 & 55 & 0.5721 \\
\hline Total triglyceride & $6(4)$ & $66(44)$ & 0.0091 \\
\hline Total cholesterol & $12(8)$ & $39(26)$ & 0.0082 \\
\hline High-density lipoprotein & $6(4)$ & $88(72)$ & 0.0063 \\
\hline Low-density lipoprotein & $45(30)$ & $25(41)$ & 0.0489 \\
\hline Apolipoprotein A & $81(54)$ & $99(66)$ & 0.0894 \\
\hline Apolipoprotein B & $24(36)$ & $75(51)$ & 0.0739 \\
\hline
\end{tabular}

$\mathrm{P}<0.05$ was considered to indicate a statistically significant difference. AS vs. controls $(\mathrm{n}=150)$. AS, atherosclerosis.

Table IV. Methylation levels of AS-associated genes in the two groups.

\begin{tabular}{llll}
\hline Gene & Healthy group & AS group & P-value \\
\hline$A C A T 1$ & $0.6103 \pm 0.01082$ & $0.4357 \pm 0.02562$ & $0.0024^{\mathrm{a}}$ \\
$I C A M 1$ & $0.2812 \pm 0.02119$ & $0.2530 \pm 0.02335$ & 0.3722 \\
$A L O X 5$ & $0.3091 \pm 0.01589$ & $0.2770 \pm 0.00573$ & $0.0325^{\mathrm{b}}$ \\
LRP1 & $0.6977 \pm 0.01104$ & $0.6893 \pm 0.01261$ & 0.6213 \\
$M M P 9$ & $0.6246 \pm 0.02744$ & $0.5585 \pm 0.02754$ & 0.0944 \\
TIMP1 & $0.5103 \pm 0.00276$ & $0.5924 \pm 0.00782$ & $0.0031^{\mathrm{a}}$ \\
$V E G F A$ & $0.5607 \pm 0.00841$ & $0.5565 \pm 0.01386$ & 0.8073 \\
$P D G D B$ & $0.5493 \pm 0.01008$ & $0.5217 \pm 0.01175$ & 0.0812 \\
$A B C A 1$ & $0.4855 \pm 0.006517$ & $0.6708 \pm 0.01609$ & $0.0011^{\mathrm{a}}$ \\
$L C A T$ & $0.7087 \pm 0.01502$ & $0.6827 \pm 0.01682$ & 0.2544 \\
$P P A R A$ & $0.9944 \pm 0.00215$ & $0.9786 \pm 0.00147$ & $0.0266^{\mathrm{b}}$ \\
$N F K B 1$ & $0.5709 \pm 0.01952$ & $0.5631 \pm 0.007049$ & 0.7090
\end{tabular}

${ }^{\mathrm{a}} \mathrm{P}<0.01,{ }^{\mathrm{b}} \mathrm{P}<0.05$ vs. healthy group. Values are presented as the mean + standard deviation. AS, atherosclerosis.

the following factors: Total cholesterol (TC; $\mathrm{P}=0.0082)$, total triglycerides (TG; $\mathrm{P}=0.0091$ ), high-density lipoprotein (HDL; $\mathrm{P}=0.0063)$, apolipoprotein $\mathrm{A}(\mathrm{P}=0.0895)$ and apolipoprotein $\mathrm{B}$ $(\mathrm{P}=0.0739)$ compared with the matched control subjects, however, the low-density lipoprotein (LDL) is decreased. The two groups were matched according to gender, age, smoking habit and alcohol consumption; Table III presents the clinical profiles of the patients.

Blood lipid levels. The 300 samples were evaluated using an automatic biochemical analyzer and the blood lipids levels are presented in Fig. 2. Compared with the healthy control group, the concentrations of TG and TC increased by 2.4- and 1.2-fold, respectively in the AS patients $(\mathrm{P}<0.01$ and $\mathrm{P}<0.05)$, while, the HDL level was reduced by $43.8 \%$ in the AS group $(\mathrm{P}<0.05)$.

Methylation frequencies of target genes in the AS and matched control subjects in the test set. DNA methylation of $A B C A 1$, ACAT1, PPARA, PDGFB, ALOX5, LRP1, LCAT, TIMP1, $M M P 9, I C A M 1, V E G F A$ and NFKB1 were initially assessed by NT-MSP (Fig. 3; Table IV). The figure demonstrates the patterns of hyper- and hypomethylated genes in the AS patients and matched control subjects. Methylation frequencies of ACAT1 $(\mathrm{P}<0.01), A L O X 5(\mathrm{P}<0.05)$ and PPARA $(\mathrm{P}<0.05)$ were decreased whereas TIMPI $(\mathrm{P}<0.01)$ and $A B C A 1(\mathrm{P}<0.01)$ were significantly increased in AS compared the matched controls. However, no statistically significant differences were identified 
Table V. Diagnostic performance of five genes in AS group versus the matched controls in the test set.

\begin{tabular}{|c|c|c|c|c|c|c|c|c|}
\hline \multirow[b]{2}{*}{ Gene } & \multicolumn{2}{|c|}{ AS group } & \multicolumn{2}{|c|}{ Matched control group } & \multirow[b]{2}{*}{ AUC } & \multirow[b]{2}{*}{ PPV } & \multirow[b]{2}{*}{ NPV } & \multirow[b]{2}{*}{ P-valu } \\
\hline & Sensitivity (\%) & Pos./total & Specificity (\%) & Pos./total & & & & \\
\hline TIMP1 & 78 & $117 / 150$ & 84 & $24 / 150$ & 0.891 & 0.83 & 0.79 & $<0.0001$ \\
\hline ACAT1 & 68 & $102 / 150$ & 84 & $24 / 150$ & 0.830 & 0.81 & 0.72 & $<0.0001$ \\
\hline$A B C A 1$ & 62 & $90 / 150$ & 78 & $33 / 150$ & 0.711 & 0.74 & 0.67 & $<0.0001$ \\
\hline ALOX5 & 48 & $72 / 150$ & 60 & $60 / 150$ & 0.547 & 0.55 & 0.54 & 0.0325 \\
\hline PPARA & 44 & $66 / 150$ & 72 & $42 / 150$ & 0.535 & 0.61 & 0.56 & 0.0380 \\
\hline
\end{tabular}

AS, atherosclerosis; AUC, area under the curve; Pos., presented positive; PPV, positive predictive value; NPV, negative predictive value. $\mathrm{n}=150$.

Table VI. Diagnostic performance of different panels in the AS and matched groups.

\begin{tabular}{|c|c|c|c|c|c|c|}
\hline \multirow[b]{2}{*}{ Genes } & \multicolumn{2}{|c|}{ AS group } & \multicolumn{2}{|c|}{ Matched control group } & \multirow[b]{2}{*}{ PPV } & \multirow[b]{2}{*}{ NPV } \\
\hline & Sensitivity (\%) & Pos./total & Specificity (\%) & Pos./total & & \\
\hline ACAT1, TIMP1 & 84 & $126 / 150$ & 78 & $33 / 150$ & 0.79 & 0.81 \\
\hline$A B C A 1, T I M P 1$ & 76 & $114 / 150$ & 94 & $9 / 150$ & 0.93 & 0.80 \\
\hline$A C A T 1, A B C A 1$ & 76 & $114 / 150$ & 74 & $39 / 150$ & 0.75 & 0.76 \\
\hline ACAT1, ABCA1, TIMP1 & 88 & $132 / 150$ & 90 & $15 / 150$ & 0.90 & 0.88 \\
\hline
\end{tabular}

AS, atherosclerosis; Pos., presented positive; PPV, positive predictive value; NPV, negative predictive value. $n=150$.

between the remaining genes ( $P D G F B, L R P 1, L C A T, M M P 9$, $I C A M 1, V E G F A$ and NFKBI) in the AS patients and matched control subjects, thus, these genes were excluded. The methylation of TIMP1, ACAT1 (P<0.01), ABCA1, ALOX5 and PPARA were significantly different in AS; thus, these genes may be used as a clinical tool for the early diagnosis of AS.

Aberrant methylation profiles in AS. Among the 12 genes, the methylation frequencies of five genes, TIMPI, ACATI, ABCA1, $A L O X 5$ and PPARA, were significantly different between the AS patients and the matched control subjects. ROC curves were constructed for each of the five genes to classify AS patients and the matched control subjects. The area under the curve (AUC) of the ROC curve for TIMPI was $0.891(\mathrm{P}<0.0001)$, which was the largest among the five genes. The sensitivity and specificity of $T I M P I$ were 78 and $84 \%$, respectively, in the diagnosis of AS (Table V). When used separately to diagnose AS, the sensitivity of each gene ranged from 44 to $78 \%$ and the specificity ranged from 60 to $84 \%$, the AUC of the ROC curves for the other four genes (ACAT1, ABCA1, ALOX5 and PPARA) ranged from 0.547 to 0.830 .

Combining various markers is a common strategy to improve diagnostic sensitivity when investigating clinical biomarkers. Based on the ROC curve for each gene, the most sensitive for the diagnosis of AS was TIMP1, which was found to be methylated in 117 of the 150 cases of AS patients, displaying a sensitivity of $78 \%$; TIMPI was also identified in 126 of the 150 cases of matched controls, displaying a specificity of $84 \%$ (Table V). The more frequently methylated gene

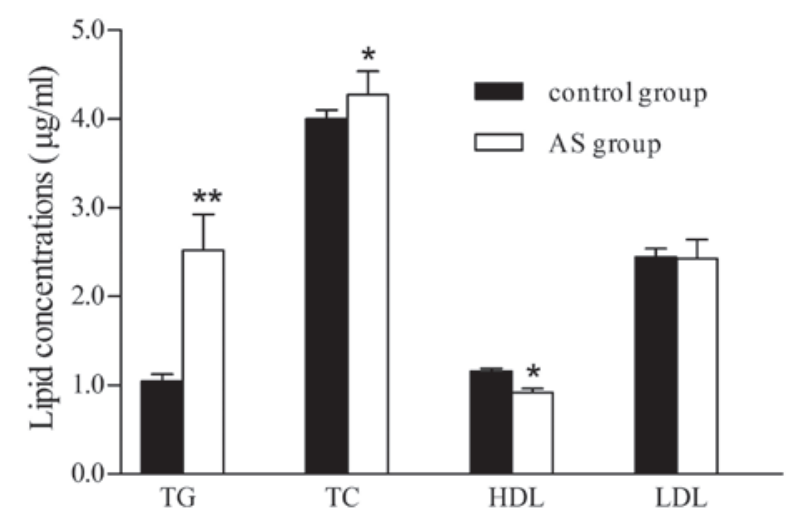

Figure 2. Blood lipid concentrations. ${ }^{*} \mathrm{P}<0.05$, ${ }^{* * *} \mathrm{P}<0.01$ vs. control group. TG, triglyceride; TC, total cholesterol; HDL, high-density lipoprotein; LDL, low-density lipoprotein.

was ACATl (68\%; 102/150), followed by ABCAl (62\%; 93/150), ALOX $5(48 \% ; 72 / 150)$ and PPARA $(44 \% ; 66 / 150)$. The AUC of ALOX5 (0.547) and PPARA (0.535) was the smallest among the five genes, and the methylation frequencies of ALOX5 and PPARA demonstrated no significant difference between the AS and matched control groups, ranging from 44 to $48 \%$ and from 60 to $72 \%$ in the in AS and matched control groups, respectively. Three genes, TIMPI, ACAT1 and ABCA1, were highly specifically methylated in AS; therefore, these constituted the first combination $(\mathrm{P}<0.01)$, which was the highest among the five genes for the diagnosis of AS. According to this analysis, combinations of different markers were examined to 
Table VII. AS-associated gene mRNA expression in the two groups.

\begin{tabular}{lrrr}
\hline Gene & Healthy group & AS group & P-value \\
\hline ACAT1 & $0.1027 \pm 0.02326$ & $0.1585 \pm 0.03378$ & $0.0348^{\mathrm{a}}$ \\
ABCA1 & $0.4492 \pm 0.12360$ & $0.1046 \pm 0.02010$ & $0.0156^{\mathrm{a}}$ \\
ALOX5 & $0.07529 \pm 0.01171$ & $0.2545 \pm 0.05715$ & $0.0040^{\mathrm{b}}$ \\
TIMP1 & $0.1477 \pm 0.01251$ & $0.05062 \pm 0.00502$ & $0.0001^{\mathrm{b}}$ \\
PPARA & $0.0861 \pm 0.02322$ & $0.33960 \pm 0.06839$ & $0.0025^{\mathrm{b}}$ \\
\hline
\end{tabular}

${ }^{\mathrm{a}} \mathrm{P}<0.05,{ }^{\mathrm{b}} \mathrm{P}<0.01$ vs. healthy group. Values are presented as the mean + standard deviation. AS, atherosclerosis.
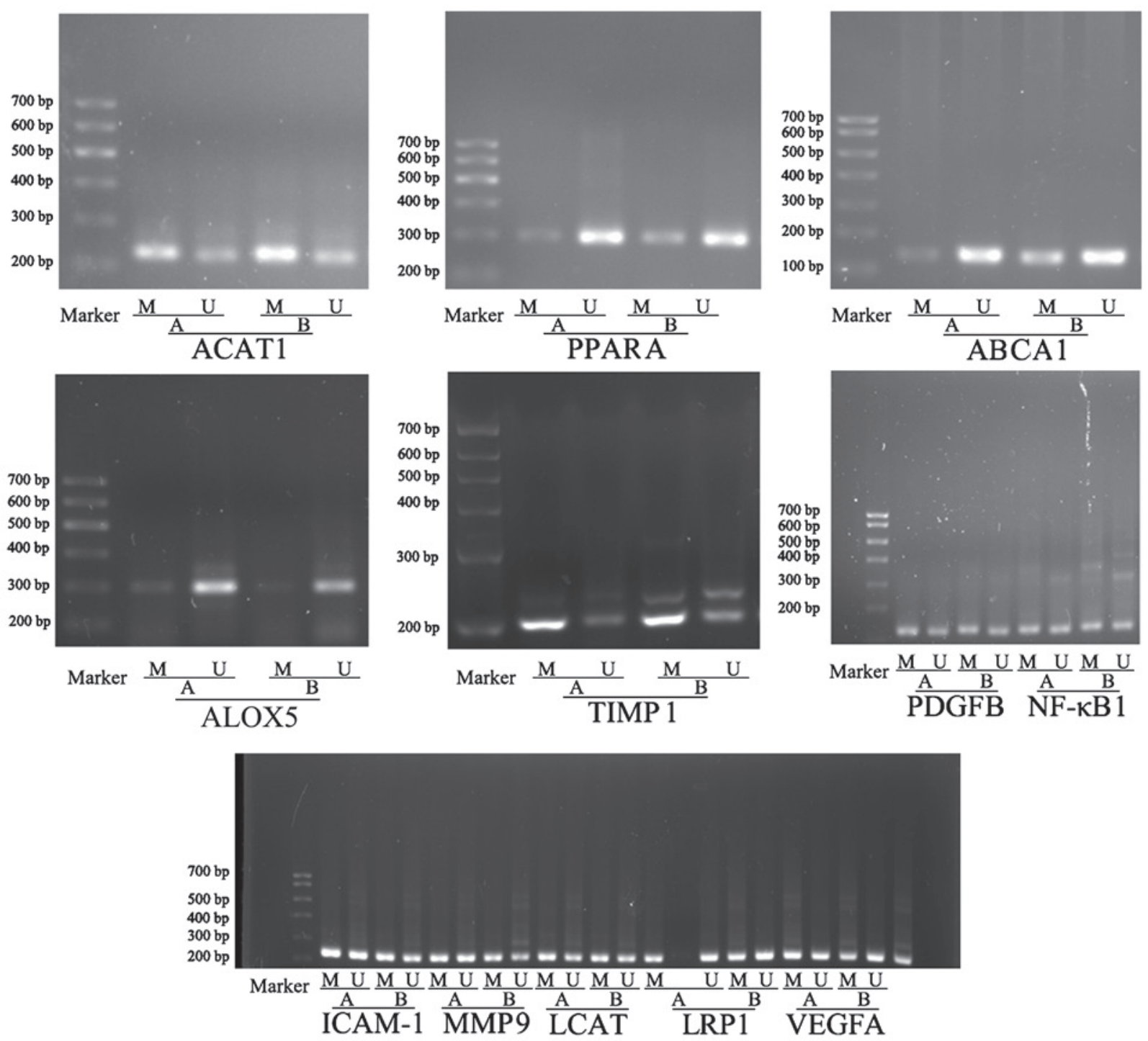

Figure 3. Methylation of AS-associated genes. Nested touchdown methylation-specific polymerase chain reaction was performed following bisulfite modification of DNA from samples of peripheral blood from the healthy and AS groups. Lane M, methylation; lane U, unmethylation; lane A, healthy group; lane B, AS group. AS, atherosclerosis.

maximize specificity and sensitivity (Table VI). The combination of TIMP1, ACAT1 improved the sensitivity to $84 \%$, which is higher than TIMP1 or ACAT1 alone, while the specificity dropped to $78 \%$. Using this method, a total of three panels of genes were analyzed. The sensitivity and specificity of the three-gene panel (TIMP1, ACAT1 and ABCA1) was 88 and
$90 \%$, respectively and thus was identified to be the optimal combination of markers in the present study.

Expression levels of TIMP1, ACAT1, ABCA1, ALOX5 and PPARA in the AS and matched control groups. DNA methylation is often correlated with changes in the accessibility of DNA 
to transcriptional activators, which is crucial in the regulation of gene expression (26). RT-qPCR analysis of these five genes (TIMP1, ACAT1, ABCA1, ALOX5 and PPARA) was performed in the AS and matched control groups on samples of peripheral blood for which total RNA was available. Compared with the healthy group, the expression levels of PPARA, ALOX5 and ACAT1 were increased by 3.94-, 3.38- and 1.54-fold in the AS group, respectively (Table VII). These data suggest that these AS-associated genes were markedly altered in AS patents.

Analysis of sensitivity and specificity of methylation profiles. The novel panel, consisting of the genes TIMP1, ACAT1 and $A B C A 1$, initially exhibited a combined sensitivity of $88 \%$ for the AS group and specificity of $90 \%$ for the matched control group, the performance of the novel panel was higher when compared with that of the individual genes for the detection of AS. The novel epigenetic (epi)-panel was compared with the previously used Doppler ultrasound method to identify AS in the validation data analysis. The validation set consisted of 100 samples that were also obtained from the General Hospital of Ningxia Medical University, including 50 patients and 50 healthy individuals, who had been excluded from the AS group via Doppler ultrasound diagnosis.

To study the correlation between methylation levels obtained by NT-MSP and Doppler ultrasound (which is a diagnostic criteria for AS) samples of the validation set were reexamined by qualitative NT-MSP. In order to increase the analytical sensitivity and to yield a higher reproducibility, primer binding sites in the test set and the validation set were located in the same genomic promoter region. By contrasting Doppler ultrasound with TIMP1,ACAT1 and $A B C A 1$ promoter methylation, a significant, positive correlation was identified. The combination of TIMP1, ACAT1 and ABCA1 methylation revealed a sensitivity of $88 \%$ for the detection of AS and a specificity of $70 \%$ in healthy subjects, respectively. The novel panel also revealed a coincidence rate of $79 \%$, which refers to consistency between the results of the novel panel and the Doppler ultrasound.

\section{Discussion}

The incidence of AS is increasing and represents a significant health issue, thus, there is a clear requirement for the development of prognostic markers in AS to provide risk-adjusted treatment and surveillance management. DNA methylation biomarkers have obvious applications in diagnostics (27). In the present study, the performance of a blood-based PCR assay for methylated DNA of 12 potential biomarkers was determined in two independent test sets with a total of 300 samples. The data confirmed the high performance of certain previously identified DNA methylation markers. Furthermore, the methylation frequencies of ACAT1, ABCA1, PPARA, TIMPI and $A L O X 5$ of AS peripheral blood were identified to be significantly changed when compared with that of the matched controls, the novel epi-panel consisting of TIMP1, ACAT1 and $A B C A 1$ exhibited a higher sensitivity and specificity than any of the individual biomarkers.

These genes have previously been reported to be significantly involved in preventing or promoting AS. Aberrant methylation of $A B C A 1$ and $A C A T 1$ has been identified in the progression of AS (28). In addition, TIMPI expression has been associated with a negative prognosis in AS (29). To the best of our knowledge the present study is the first to demonstrate TIMP1 methylation in AS, and that methylation of ACAT1 and $A B C A 1$ has never previously been reported in AS.

Methylation changes in AS are often heterogeneous and, as yet, to the best of our knowledge, no single gene has been identified to be methylated in every AS patient specimen. Furthermore, in the majority of studies investigating methylation levels of only single genes the sensitivity was low. Therefore, it is considered to be advantageous to use a panel of genes for disease screening procedures. As a result of the comparative analysis, a biomarker panel with the best values for AS specificity was defined first in a test set. TIMP1, ACAT1 and $A B C A 1$ proved to be candidate genes, showing a significant specificity of the methylation pattern in the matched control and AS groups. Furthermore, TIMPI, ACAT1 and $A B C A 1$ methylation achieved $88 \%$ sensitivity, with a high specificity of $90 \%$ in the test set, this indicated that the panel had the potential to perform as effectively, potentially more effectively, than the single markers, indicating that the methylation of three genes may be useful when screening high risk individuals.

In an independent validation set, promoter methylation of the TIMPI, ACATI and ABCAI combination enabled significant discrimination of AS from various control conditions. ROC analysis of three-gene panel methylation revealed a sensitivity of $88 \%$ with a specificity of $70 \%$. Combining these with other detection methods may provide a robust epi-panel with a high sensitivity for AS detection. Compared with ultrasound, a reliable biomarker panel for the early detection of AS, revealed that the coincidence rate was 79\%; thus, TIMP1, $A C A T 1$ and $A B C A 1$ methylation analyses may be used as a supplement to mammography, which has a low sensitivity in the early detection of AS.

In conclusion, methods for AS screening should be easy to perform, non-invasive and provide a benefit to patients. Blood-based biomarkers fulfill these three requirements. Quantifying promoter methylation of AS-associated genes in peripheral blood is a rapidly growing research topic for early AS detection. In the current study, 12 potential biomarkers were evaluated in two independent test sets, and promoter methylation of the TIMPI, ACATI and ABCAl gene combination exhibited a high sensitivity and specificity in peripheral blood DNA from patients with AS. It is proposed that such a blood-based screening method would be convenient for the patient and reduce costs for health care providers.

\section{Acknowledgements}

The present study was supported by grants from the National Natural Science Foundation of China (grant nos. 81160044, 81260105, 81360073, 81200118 and 81260063).

\section{References}

1. Liapis CD, Bell PR, Mikhailidis D, Sivenius J, Nicolaides A, Fernandes e Fernandes J, Biasi G and Norgren L; ESVS Guidelines Collaborators: ESVS guidelines. Invasive treatment for carotid stenosis: Indications, techniques. Eur J Vasc Endovasc Surg 37 (4 Suppl): S1-S19, 2009. 
2. Du J, Wasserman BA, Tong W, Chen S, Lai S, Malhotra S and Lai $\mathrm{H}$ : Cholesterol is associated with the presence of a lipid core in carotid plaque of asymptomatic, young-to-middle-aged African Americans with and without HIV infection and cocaine use residing in inner-city Baltimore, Md., USA. Cerebrovasc Dis 33: 295-301, 2012.

3. Almekkaway MK, Shehata IA and Ebbini ES: Anatomical-based model for simulation of HIFU-induced lesions in atherosclerotic plaques. Int J Hyperthermia 31: 433-442, 2015.

4. Libby P: Managing the risk of atherosclerosis: The role of high-density lipoprotein. Am J Cardiol 88: 3N-8N, 2001.

5. Holling worth W, Nathens AB, Kanne JP, Crandall ML, Crummy TA, Hallam DK, Wang MC and Jarvik JG: The diagnostic accuracy of computed tomography angiography for traumatic or atherosclerotic lesions of the carotid and vertebral arteries: A systematic review. Eur J Radiol 48: 88-102, 2003.

6. Wong KS, Li H, Chan YL, Ahuja A, Lam WW, Wong A and Kay R: Use of transcranial doppler ultrasound to predict outcome in patients with intracranial large-artery occlusive disease. Stroke 31: 2641-2647, 2000.

7. Dong C, Yoon W and Goldschmidt-Clermont PJ: DNA methylation and atherosclerosis. J Nutr 132 (8 Suppl), 2406S-2409S, 2002.

8. Grützmann R, Molnar B, Pilarsky C, Habermann JK, Schlag PM, Saeger HD, Miehlke S, Stolz T, Model F, Roblick UJ, et al: Sensitive detection of colorectal cancer in peripheral blood by septin 9 DNA methylation assay. PloS One 11: e3759, 2008.

9. Majid MM, Mughal MK, DeMarco JK, Majid A, Shamoun F and Abela GS: Symptomatic and asymptomatic carotid artery plaque. Expert Rev Cardiovasc Ther 9: 1315-1330, 2011

10. Mendelsohn AR and Larrick JW: The DNA methylome as a biomarker for epigenetic instability and human aging. Rejuvenation Res 16: 74-77, 2013.

11. Guay SP, Brisson D, Lamarche B, Marceau P, Vohl MC, Gaudet D and Bouchard L: DNA methylation variations at CETP and LPL gene promoter loci: New molecular biomarkers associated with blood lipid profile variability. Atherosclerosis 228:413-420, 2013.

12. Zhang Y, Zhao M, Sawalha AH, Richardson B and Lu Q: Impaired DNA methylation and its mechanism $s$ in CD4(+)T cells of systemic lupus erythematosus. J Autoimmun 41: 92-99, 2013.

13. Robertson KD and Jones PA: DNA methylation: Past, present and future directions. Carcinogenesis 21: 461-467, 2000.

14. Zhao J, Forsberg CW, Goldberg J, Smith NL and Vaccarino V: MAOA promoter methylation and susceptibility to carotid atherosclerosis: Role of familial factors in a monozygotic twin sample. BMC Med Genet 13: 100, 2012.

15. Lasseigne BN, Burwell TC, Patil MA, Absher DM, Brooks JD and Myers RM: DNA methylation profiling reveals novel diagnostic biomarkers in renal cell carcinoma. BMC Med 12: 235, 2014.

16. Yu X, Ling W and Mi M: Relationship of impairment induced by intracellular S-adenosylhomocysteine accumulation with DNA methylation in human umbilical vein endothelial cells treated with 3-deazaadenosine. Int J Exp Pathol 90: 638-648, 2009.

17. Dong C, Yoon W and Goldschmidt-Clermont PJ: DNA methylation and atherosclerosis. J Nutr 132 (8 Suppl): 2406S-2409S, 2002.
18. Van De Voorde V, Speeckaert R, Van Gestel D, Bracke M, De Neve W, Delanghe J and Speeckaert M: DNA methylation-based biomarkers in serum of patients with breast cancer. Mutat Res 751: 304-325, 2012.

19. Ridker PM, Stampfer MJ and Rifai N: Novel risk factors for systemic atherosclerosis: A comparison of C-reactive protein, fibrinogen, homocysteine, lipoprotein(a) and standard cholesterol screening as predictors of peripheral arterial disease. JAMA 285: 2481-2485, 2001

20. Attie AD, Kastelein JP and Hayden MR: Pivotal role of ABCA1 in reverse cholesterol transport influencing HDL levels and susceptibility to atherosclerosis. J Lipid Res 42: 1717-1726, 2001.

21. Nissen SE, Tuzcu EM, Brewer HB, Sipahi I, Nicholls SJ, Ganz P, Schoenhagen P, Waters DD, Pepine CJ, Crowe TD, et al: Effect of ACAT inhibition on the progression of coronary atherosclerosis. N Engl J Med 354: 1253-1263, 2006.

22. Shan W, Palkar PS, Murray IA, McDevitt E, Kennett MJ, Kang BH, Isom HC, Perdew GH, Gonzalez FJ and Peters JM: Ligand activation of peroxisome proliferator-activated receptor beta/delta (PPARbeta/delta) attenuates carbon tetrachloride hepatotoxicity by downregulating proinflammatory gene expression. Toxicol Sci 105: 418-428, 2008.

23. Khovidhunkit W, Kim MS, Memon RA, Shigenaga JK, Moser AH, Feingold KR and Grunfeld C: Effects of infection and inflammation on lipid and lipoprotein metabolism mechanisms and consequences to the host. J Lipid Res 45: 1169-1196, 2004.

24. Liang Y, Yang X, Ma L, Cai X, Wang L, Yang C, Li G, Zhang M, Sun W and Jiang Y: Homocysteine-mediated cholesterol efflux via ABCA1 and ACAT1 DNA methylationin THP-1 monocyte-derived foam cells. Acta Biochim Biophys Sin (Shanghai) 45: 220-228, 2013.

25. Ma S, Zhang H, Sun W, Gong H, Wang Y, Ma C, Wang J, Cao C, Yang X, Tian J, et al: Hyperhomocysteinemia induces cardiac injury by up-regulation of p53-dependent Noxa and Bax expression through the p53 DNA methylation in ApoE (-/-) mice. Acta Biochim Biophys Sin (Shanghai) 45: 391-400, 2013.

26. Frangogiannis NG, Smith CW and Entman ML: The inflammatory response in myocardial infarction. Cardiovasc Res 53: $31-47,2002$

27. Glöckner SC, Dhir M, Yi JM, McGarvey KE, Van Neste L, Louwagie J, Chan TA, Kleeberger W, de Bruïne AP, Smits KM, et al: Methylation of TFPI2 in stool DNA: A potential novel biomarker for the detection of colorectal cancer. Cancer Res 69: 4691-4693, 2009.

28. Melotte V, Lentjes MH, van den Bosch SM, Hellebrekers DM, de Hoon JP, Wouters KA, Daenen KL, Partouns-Hendriks IE, Stessels F, Louwagie J, et al: N-Myc downstream-regulated gene 4 (NDRG4): A candidate tumor suppressor gene and potential biomarker for colorectal cancer. J Natl Cancer Inst 101: 916-927, 2009.

29. Hoseini SM, Kalantari A, Afarideh M, Noshad S, Behdadnia A, Nakhjavani M and Esteghamati A: Evaluation of plasma MMP-8, MMP-9 and TIMP-1 identifies candidate cardiometabolic risk marker in metabolic syndrome: Results from double-blinded nested case-control study. Metabolism 64: 527-538, 2015. 